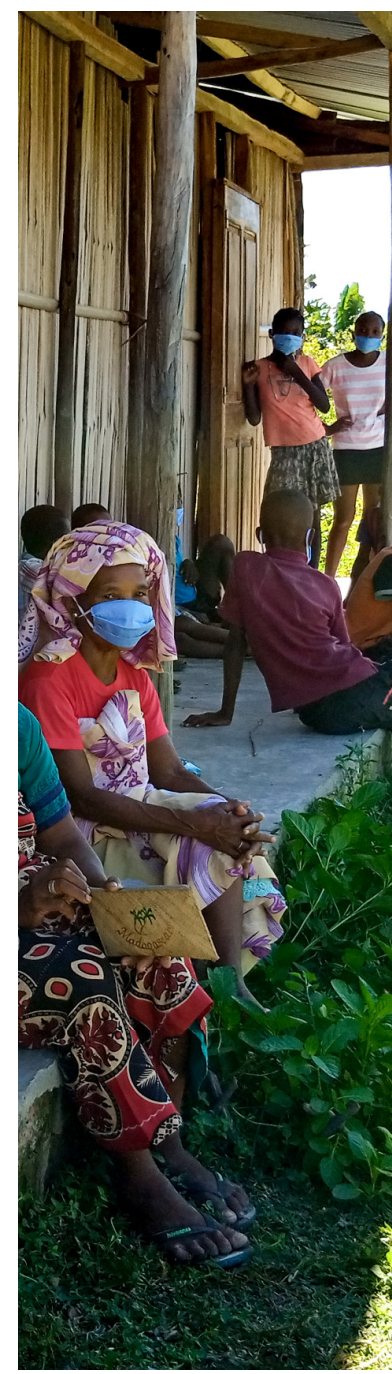

\title{
COVID-19, INDIGENOUS PEOPLES, LOCAL COMMUNITIES AND NATURAL RESOURCE GOVERNANCE
}

\author{
Gretchen Walters ${ }^{1,2}$, Neema Pathak Broome ${ }^{3}$, Marina $\mathrm{Cracco}^{1}$, Tushar \\ Dash $^{4}$, Nigel Dudley ${ }^{5}$, Silvel Elías ${ }^{6}$, Olivier Hymas ${ }^{1}$, Sangeeta \\ Mangubhai ${ }^{7}$, Vik Mohan $^{8}$, Thomas Niederberger ${ }^{9}$, Christy Achtone \\ Nkollo-Kema Kema ${ }^{10}$, Appolinaire Oussou Lio ${ }^{11}$, Njaka Raveloson ${ }^{8}$, June \\ Rubis $^{12}$, S.A.R. Mathieu Toviehou ${ }^{11}$ and Nathalie Van Vliet ${ }^{13}$
}

*Corresponding author: gretchen.walters@unil.ch

${ }^{1}$ Institute of Geography and Sustainability, University of Lausanne, Lausanne, Switzerland

${ }^{2}$ Department of Anthropology, University College London, United Kingdom

${ }^{3}$ Kalpavriksh, Apt No. 5, 908 Deccan Gymkhana, Pune 411004, Maharashtra, India

${ }^{4}$ Independent researcher and consultant, Odisha, India

${ }^{5}$ Equilibrium Research, 47 The Quays, Cumberland Road, Bristol BS1 6UQ, UK

${ }^{6}$ Facultad de Agronomía, Universidad de San Carlos de Guatemala, San Carlos, Guatemala

${ }^{7}$ Wildlife Conservation Society, Fiji Country Program, 11 Ma'afu Street, Suva, Fiji

${ }^{8}$ Blue Ventures, The Old Library, Trinity Road, Bristol, BS2 ONW, UK

${ }^{9}$ ICCA Consortium; Institute of Social Anthropology, University of Bern, Switzerland

${ }^{10}$ Université Omar Bongo, Laboratoire de Géomatique, de Recherche Appliquée et de Conseils, Université Omar Bongo 680, Avenue Léon MBA, Libreville, Gabon

${ }^{11}$ Groupe de Recherche et d'Action pour le Bien-Etre au Bénin, BP: 13 Avrankou, Benin

${ }^{12}$ ICCA Consortium Co-Chair for Documenting Territories of Life; Sydney Environment Institute, University of Sydney, Camperdown, NSW Australia

${ }^{13}$ Center for International Forestry Research, Jalan CIFOR, Situ Gede, Bogor Barat, Bogor 16115, Jawa Barat, Indonesia

\begin{abstract}
We report on how the COVID-19 pandemic is affecting Indigenous peoples and local communities (IPLCs), especially those who govern, manage and conserve their lands and waters. We explore the themes of access and use of natural resources, solidarity, decision-making, the role of governments and IPLCs in managing COVID-19, and the uptake of traditional medicine. These themes are explored through a global online survey in English, Spanish and French. We collected and analysed 133 surveys from 40 countries, using SenseMaker $\AA$, a software that enables analysis of micronarratives based on how respondents classify their own stories. We explore the themes further through case studies from Benin, Fiji, France, Gabon, Guyana, Guatemala, India and Madagascar, highlighting challenges and opportunities in how IPLCs responded to COVID-19. Our study underscores the importance of selfempowerment and recognition of IPLC rights, which allows them to use traditional medicines, meet subsistence requirements during lockdowns, help community members and neighbours to sustain livelihoods, and to govern, defend and conserve their territories. We propose key actions to support IPLCs navigate future pandemics while protecting their lands and waters.
\end{abstract}

Key words: Coronavirus, pandemic, disturbances, resilience, rights, traditional medicine, natural resources, biodiversity conservation

\section{INTRODUCTION}

The COVID-19 pandemic is having an unprecedented impact across the globe. Although we frequently hear the perspectives of governments, business and the health sector, less is known about impacts on Indigenous peoples and local communities (IPLCs). The World Bank estimates there are 476 million Indigenous people in over 90 countries, 6 per cent of the global population (World Bank, 2020). Recent estimates for IPLCs living in important biodiversity conservation areas are 1.65 billion-1.87 billion people (Rights and Resources Initiative, 2020). Local communities in rural areas are harder to define and quantify but are likely to be even more numerous. IPLCs occupy and often protect 
and conserve large territories, with tenure rights over at least $\sim 38$ million $\mathrm{km}^{2}$ in 87 countries (Garnett et al., 2018), although many still hold no formal title.

Indigenous peoples and some local communities have a distinct relationship with the environment that is fundamental to their social, cultural and spiritual lives. They often possess cultures and laws based on mutual reciprocity between humans and nature, and on the principles of safeguarding the environment for future generations. Indigenous and local knowledge, laws and principles form the basis of customary governance and management practices and are closely related to common rights over land, sea and natural resources, on more or less clearly defined territories and areas. These practices are enduring, widespread, diverse and dynamic, and have many different manifestations and names globally, but are also known under the umbrella term 'ICCAs -territories of life' - an abbreviation for "territories and areas governed, managed and conserved by custodian Indigenous peoples and local communities" (Sajeva et al., 2019).

As well as facing increased threats from climate change and the expansion of extractive and polluting industries and large-scale monocultures, IPLCs may have high rates of pre-existing health problems and poorer nutrition that leave them more susceptible to the COVID-19 pandemic (IWGIA and ILO, 2020; UN InterAgency Support Group on Indigenous Issues 2020). In Brazil (Santos et al., 2020; Conde, 2020) and the United States, IPLCs are suffering more from the disease than other people. Elsewhere, they appear less affected, and may sometimes be better placed to resist COVID-19 due to strategies adopted after previous epidemics (Banning, 2020; Bayha \& Spring, 2020; Crooks et al., 2020; The Lancet, 2020).

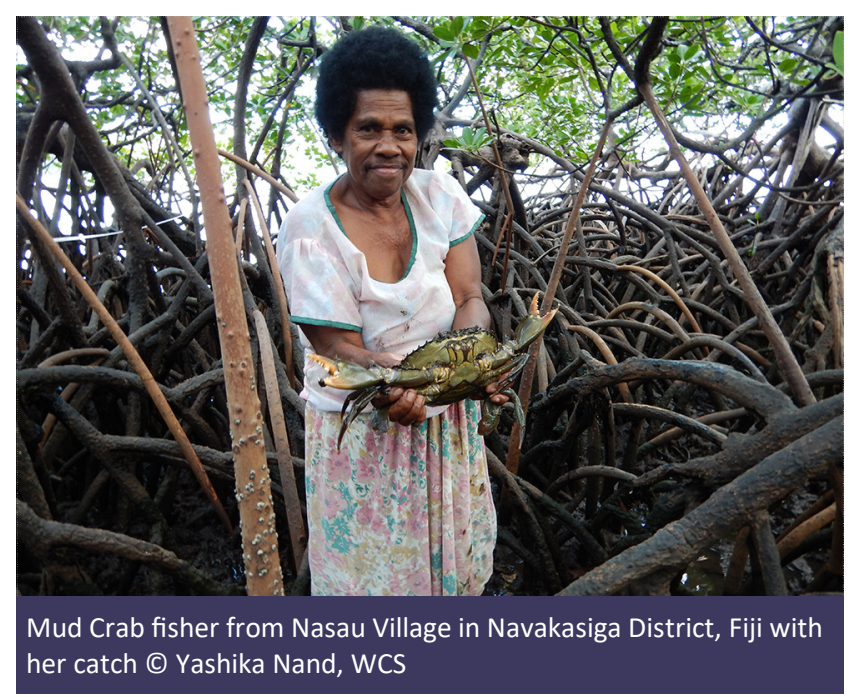

Much of the work published to date on COVID-19, in scientific papers or the media, is anecdotal, due to the difficulty of conducting fieldwork. Early in the crisis, publications summarised reports from the media or policy organisations (Belaïdi \& Koubi, 2020; Bennett et al., 2020), proposed experience-based recommendations (Meneses-Navarro et al., 2020; Power et al., 2020), or shared stories about how IPLCs were dealing with COVID-19 (Curtice \& Choo, 2020). In terms of nonpublished material, many IPLC groups held webinars about COVID-19, which explored some of the themes of this paper. However, these webinars are not always recorded, or notes are not made available, making examination of their content and long-term reference to their conclusions difficult.

Researchers have been encouraged to redirect work with community partners to support the COVID response (Bennett et al., 2020) and to combine anecdotal observations, systematic assessments and quantitative monitoring to produce new insights (Bates et al., 2020). This paper is an attempt to understand what is happening globally, beyond single territories, through a preliminary analysis of an online survey and case studies. We consider how COVID-19 has affected IPLCs, as reported by themselves and related organisations. We focus on resilience and health responses and what this may mean for access to, use of and defence of their territories, lands and waters.

\section{METHODS}

COVID-19 required that distant methods of survey be adopted. Online surveys have become more common, but have their own challenges including uneven internet access, limited language translation, unrealistic expectations of literacy and computer savviness, and poor response rates (Bernard, 2017).

We used SenseMaker ${ }^{\circledR}$, a tool enabling rapid, quantitative analysis of stories (Milne, 2015; Van der Merwe et al., 2019; Omoding et al., 2020). SenseMaker ${ }^{\circledR}$ helps analyse multiple perspectives of complex situations through identification of patterns around topics of interest and allows for meta-analysis of qualitative data bridging the gap between case studies and large-sample survey data. Through SenseMaker ${ }^{\circledR}$, respondents were encouraged to:

Please share an experience about the COVID-19 disease that shows how it has affected or is affecting Indigenous peoples' and local communities' use and relationship with their territories, lands and waters. This experience can be about you, your family, your community, or a community you work with. It could be a good, bad or neutral experience. It can be long or short. 
Sub-questions enabled respondents to add meaning to their story, signifying its importance and reducing the risk of imposing researchers' bias. Sub-questions focused on resource use and access, decision-making about COVID-19, economic, environmental and social impacts, traditional medicine, solidarity and conflict with families, communities and outsiders, community rights, community leaders and lessons from past epidemics. COVID-19 health measures and restrictions (e.g. lockdown, social distancing) were recorded, as were emotions related to stories shared. Before participating in the survey, respondents were told its objective and their consent secured. Only adults participated ${ }^{1}$. The analysis below presents triangle diagrams (e.g. Fig. 1), where respondents classified their story by placing a dot representing their story content in relation to the labels at the triangle endpoints; these triangles were further classified by other categories, such as emotional tone, gender and country. The closer the dot is to a corner, the stronger the statement is for the respondent's experience. A dot placed in the center of the triangle shows that the three elements in the corners of the triangle are equally important to the respondent. In the histograms, respondents rated their story by placing a dot along a line of opposing ideas.

The survey was developed by ICCA Consortium Members, Secretariat and Honorary Members, through online meetings in French, English and Spanish between May and July 2020. The questionnaire was developed in these three languages and tested, and further informed by a webinar series by ICCA Consortium Members ${ }^{2}$. It was promoted to ICCA Members and Honorary Members via email and social media and sent to other organisations working with IPLCs, notably through IUCN's Commission on Environmental, Economic and Social Policy and World Commission on Protected Areas, and the International Land Coalition. Some authors further circulated the survey at the community level in France, Gabon and Guyana. When researchers were living in communities, face-to-face interviews were conducted (e.g. Gabon) following protocols to protect interviewees and researchers. The survey opened on 7 August 2020 and the results presented here were collected until 9 November 2020. The survey remains open into 2021, when a second, in-depth analysis will be made.

The survey specifically sought replies from IPLCs, notably, as expressed in the survey form, from respondents who: identify as an Indigenous person; are from a community with close connections to their territories, lands and waters; or are from an organisation working with these communities.

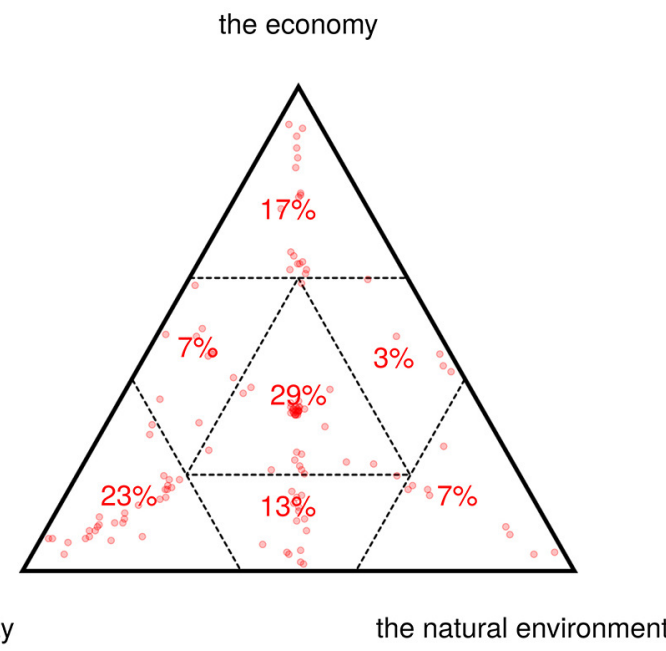

Figure 1. Percentage of responses that reflect the importance respondents placed on economic, societal or environmental factors. The percentages represent the proportion of answers in each sub-shape in the triangle.

\section{RESULTS}

Results are based on 133 answers, obtained to date, from 40 countries, 86 male and 45 female respondents, with two preferring not to say. Answers came from 30 members of the ICCA Consortium, and with a similar number of respondents who self-identified as belonging to an ICCA-territory of life. Sixty-one respondents are from organisations working with IPLCs, while 69 come from community members, including healers, leaders, governmental and conservation authorities; three preferred not to say. Of these 69 answers, 18 were from Gabon and 21 from Guyana, while other responses came from the 38 other countries. Geographically for all respondents, 51 are from Africa, 43 from Central and South America and the Caribbean, 15 from Europe, 13 from Asia and the Middle East, 6 from North America, 3 from Oceania, and 2 preferring not to say. We acknowledge that the response rate is low, which is typical of remote surveys. We note that IPLCs live in a variety of legal contexts, have different coping mechanisms and medicines, so we consider this to be a preliminary study. However, the survey results may help raise awareness of the issues surrounding IPLCs and COVID-19.

\section{Survey results and case studies}

Summary of key survey findings

In general, respondents felt that COVID-19 impacted them more in terms of social (23 per cent) and economic issues (17 per cent) than environmental ones (7 per cent); however, 29 per cent give equal importance to social and environmental issues (Fig. 1). The following 
sections report on the survey results, illustrated by case studies.

\section{COVID-19 and traditional medicine use}

Survey results

Overall, the usage of traditional medicine was perceived to be high (Fig. 2a), with the emotion of pride being particularly associated with 50 per cent of stories related to traditional medicine (Fig. 2b). The case from Guatemala shows ways in which traditional medicine has been used.

Case study 1: Use of traditional medicine by Indigenous peoples in Guatemala

The Indigenous peoples of Guatemala have counteracted the impacts of COVID-19 by mobilising knowledge and health practices inherited from their ancestors. This is not the first time they have faced these phenomena: diseases brought by the European invasion killed 80 per cent of the original population (Cook \& Lovell, 1991). Indigenous peoples are again relying on traditional medicine since governmental health assistance has historically discriminated against them, a situation which continues in the current pandemic with assistance that is scarce and late (IACHR, 2020). According to one man from a Guatemalan Indigenous community, "Doctors in the hospitals complained that they do not have the necessary tools to care for the patients". Given the lack of access to conventional medicine, the traditional therapies of Guatemala's Indigenous peoples, used to face diseases in the past, have been widely adopted to reduce the spread and impact of COVID-19.

In Guatemala, there are many Indigenous medical graduates from universities, some of whom combine scientific knowledge with traditional knowledge in the therapies they recommend. Indigenous medicine has been important in strengthening people's immune systems (also referred to as "taking care of the body and mind"), controlling fever and reducing respiratory congestion (Comunidad Maya Los Chenes, 2020). It includes mainly native plants found in ancestral territories, both in backyard gardens and in natural areas protected by communities. Steam baths - called tuj, chuj or temascal - are used by the K'iché, Mam, Kaqchikel and Ixil peoples with native plant species to improve the respiratory system. Most rural, Indigenous households have baths of this type. The Q'eqchí people used infusions of wild Guava leaves (Psidium guajava); the Ch'orti, use Quina (Cinchona offinalis), a plant from which the malarial treatment quinine is extracted. Q'eqchi, Ch'orti and other communities use Tres Puntas (Neurolaena lobata) for its antibiotic, anti-malarial, anti -ophidian and anti-inflammatory properties. Plantain (Plantago major), a naturalised species known for its expectorant properties, is also used.

Mayan Indigenous peoples have developed therapies that include ginger, garlic, eucalyptus and honey, sometimes complemented with conventional medicines depending on symptom severity. Although there are no

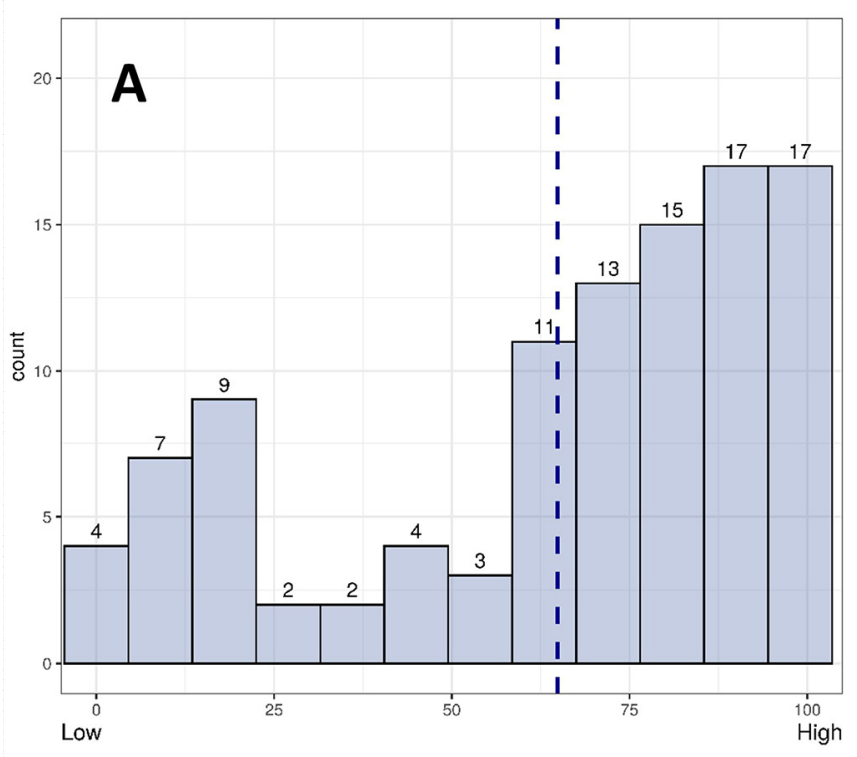

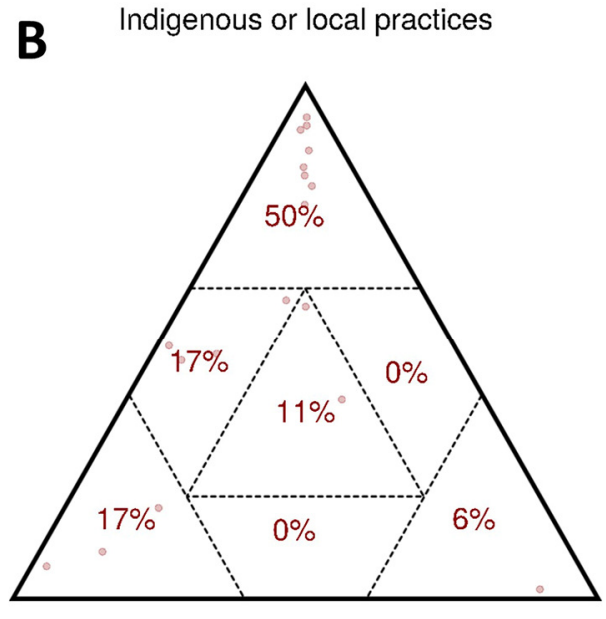

government

non-profit organisations

Figure 2. Use of traditional medicine to counteract symptoms of COVID-19. (A) The number of stories: totals are given above each bar, the dashed vertical line is the median; traditional medicine was often considered to be "highly used'. (B) Stories concerning traditional medicine: in the case of Indigenous and local practices, $\mathbf{5 0}$ per cent of stories were associated with pride. 


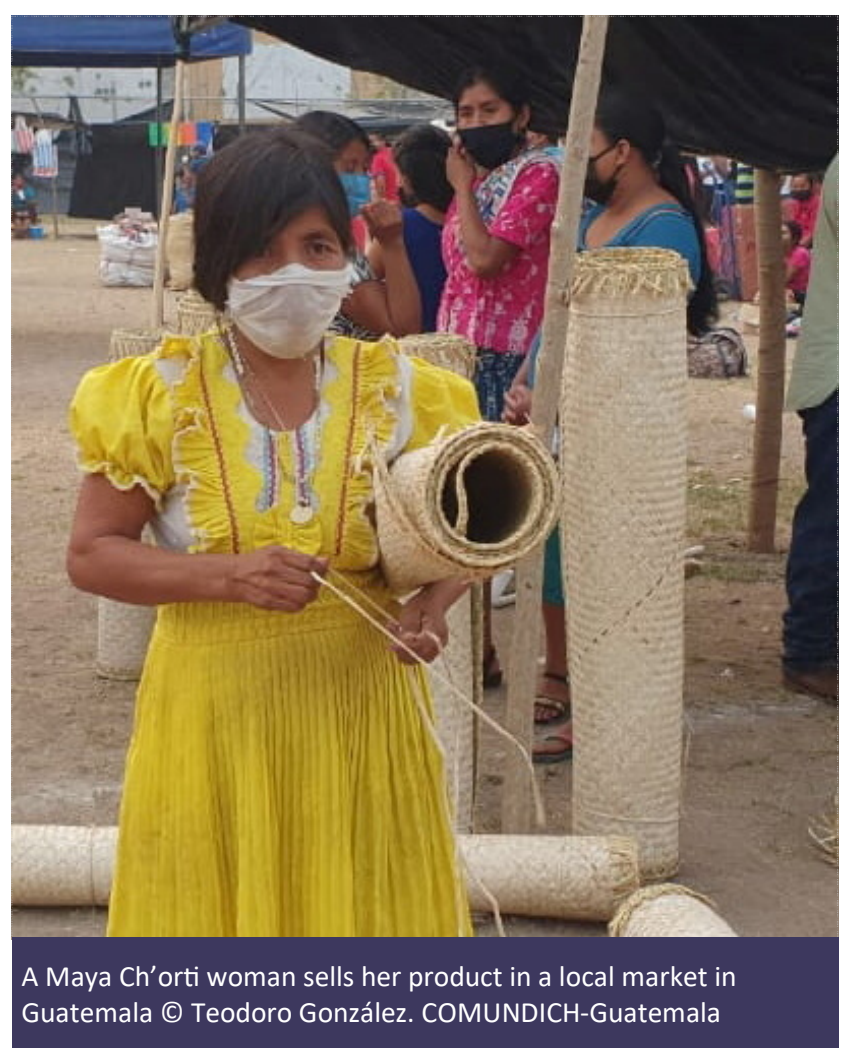

known Guatemalan Indigenous therapies capable of curing COVID-19, such medicines have been widely used to reduce the contagion and impact by strengthening immune system response.

\section{Solidarity}

COVID-19 was considered to have increased community solidarity (Fig. 3). A male Maasai community member from Tanzania reported that when the youth lost their tourism jobs, they returned home and, despite reduced family income, "helped my community to reclaim pieces of lands which have been taken forcibly by cultivators following their absence. The youth who came back to their ancestral land, united in numbers and claimed their land."

Case study 2: iTaukei communities in Fiji resilient in the face of COVID-19 but vulnerable to natural disasters

Fiji recorded its first COVID-19 case on 19 March 2020 and has had a total of 32 cases and 2 deaths (as of 15 October 2020). Telephone interviews in May 2020 with key informants from 20 rural Indigenous Fijian (iTaukei) communities across four provinces found that, while most people interviewed listed COVID-19 as a major event, there is little evidence of this affecting food security or fisheries livelihoods (WCS and LMMA, 2020). Over 90 per cent of all respondents had enough,

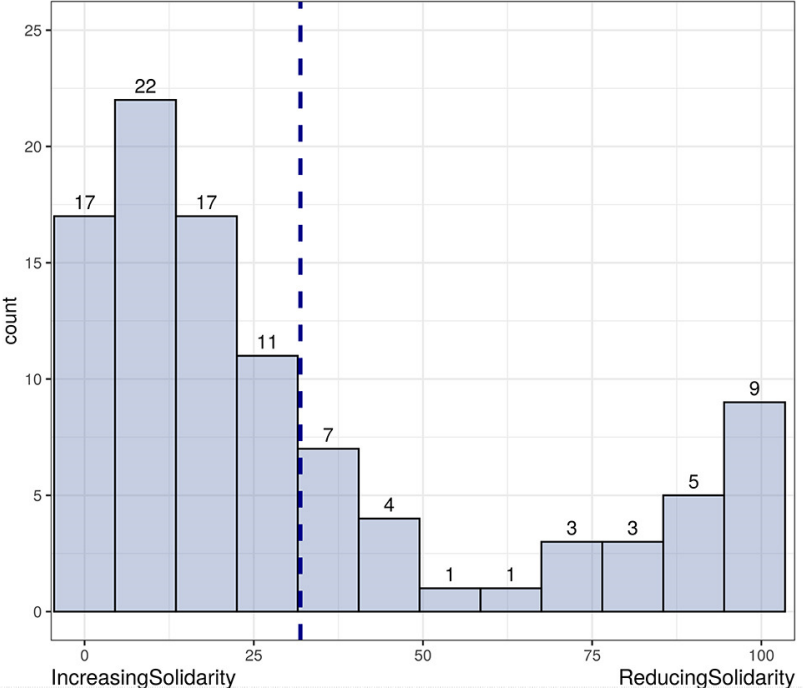

Figure 3. Stories reported increases of solidarity; the dashed, vertical line indicates the median. Numbers on top of each bar notes the number of stories.

more than enough or lots of food, from gardens and local fishing grounds. Just under a fifth of people stated their communities had suffered damage to crops from cyclone Harold which passed through Fiji in April 2020, affecting local livelihoods and household income. It appears that the iTaukei communities have been resilient to the shocks of the pandemic in the initial months of border closure and restrictions, but more affected by cyclones. Many villagers made decisions to close their village to self-isolate themselves from the rest of the country.

Land and marine tenure systems underpin natural resource management in Fiji, with 88 per cent of the land legally owned by iTaukei clans (Mangubhai et al., 2019). There were reports of support for family members returning to their villages. A woman working for an organisation in Fiji reported that "solesolevaki, a form of cultural social capital" had allowed returning villagers who had "lost their jobs in hotels when the international borders closed" to have access to food while they waited to harvest their plantations. Some concerns were raised that those returning to villages were breaking customary rules, including catching turtles and undersized fish, fishing or selling fish without a license, and poaching in the village tabus (traditional closures) (WCS and LMMA, 2020). These are commonly reported issues and offences even during normal times.

\section{Capacity of communities to govern their lands}

In the survey, COVID-19 was found to both reinforce and undermine community rights (Fig. 4a). Twentythree per cent of stories involved access, and 21 per cent 
concerned the use of natural resources (Fig. 4b). Restrictions sometimes prevented communities from protecting their lands. Some communities reported that their own movement was restricted, while private sector activities continued. An employee of an organisation working with IPLCs in Gabon, noted: Our project had begun facilitating a formal MOU [memorandum of understanding] between a logging company and villages on the co-management of hunting, but when COVID-19 arrived in the country the loggers stopped progress on this collaboration, citing the pandemic as the reason, while continuing to open roads further and further into the forest without controlling access and cutting down trees outside the knowledge of the villages. In Cameroon, another such employee said: "During this same period, they have witnessed the conversion of forest land to non-forest land, especially for the establishment of palm trees, which has led to the massive arrival of employees (including those carrying the virus) in the communities..." Similar observations were made elsewhere in Cameroon and the Democratic Republic of Congo.

An employee of an organisation working with fishing communities living outside a national park in Gabon, reported that “... park managers... banned ... residents from fishing in the park" during COVID-19, even though these fishing rights had been retained since the park was first established. As this situation has persisted for several months, the community "has initiated a process with the managers of the park without success. The inhabitants ... have taken the case to the courts and ... provincial authorities."

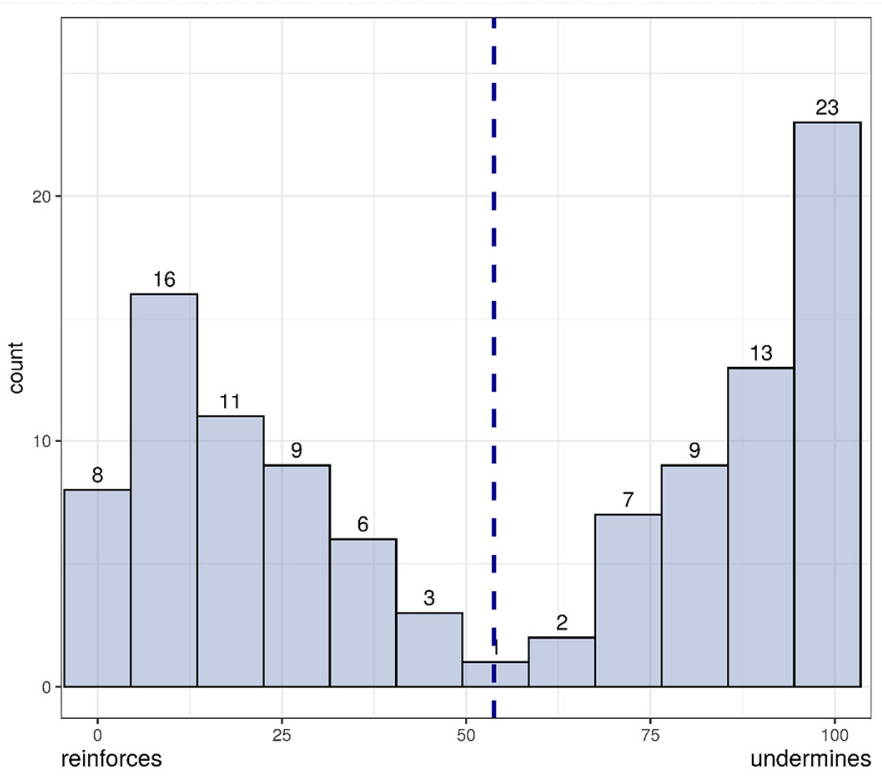

In other places, communities were able to effectively protect and use their lands, or were closed off from their lands, as explored in the case studies from India and France.

Case study 3: Empowered local communities are better equipped to deal with crisis in India 3

India continues to be one of the worst-affected countries. The pandemic and lockdown have had a drastic impact on poor and marginalised communities, with the Adivasi and other traditional communities particularly affected. These have long faced disempowerment, but where they enjoy de facto or legal rights, hundreds of Adivasi communities have shown remarkable resilience in coping with the crisis. This has

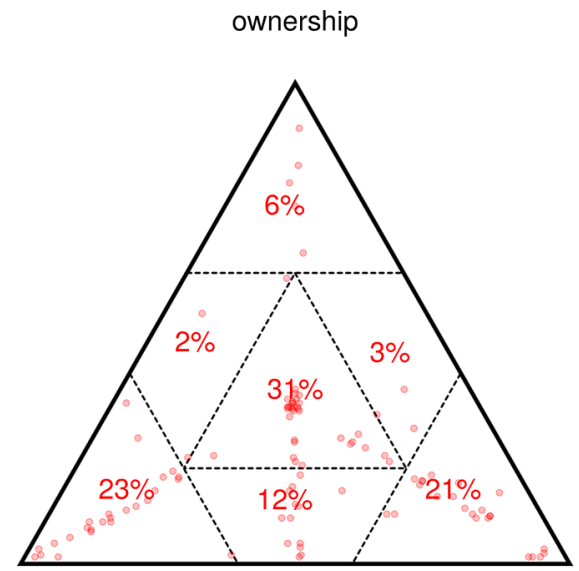

access

Figure 4b. COVID-19 stories focused largely on access or resource use, or a combination of all factors
"The restrictions that have been established in the country, especially in indigenous communities, affected the mobilization of people causing the loss of their jobs. They were also unable to attend to their crops in the established timeframes, generating losses in their harvests and affecting food security. Similarly, people could not carry out the patrols against illegal logging and fires could not be adequately prevented, which directly affected the forests."

Member of an Indigenous organisation in Guatemala

Figure 4a. COVID-19 was perceived to both reinforce and undermine community rights 
been most evident where land and forest rights are recognised under The Scheduled Tribes and Other Traditional Forest Dwellers (Recognition of Forest Rights) Act 2006 (FRA) and Panchayat Extension to Scheduled Areas Act 1996. New rights to manage community forests allowed communities to quickly address COVID-19 and the lockdown before any outside agency reacted. Key lessons emerged (Vikalp Sangam and CFR-LA, 2020), based on interviews with the community members and others:

1. Local actors understand local complexities and can act faster when empowered.

2. Secure tenure and empowerment helped gram sabhas (village assemblies) to address distress and reduce out-migration prior to the lockdown, by creating local ecosystem-based livelihoods. Consequently, community members did not face the acute crisis suffered by many migrant workers.

3. Healthy and diverse ecosystems resulting from long-term conservation helped community resilience by supplying basic needs when other options closed, including where pastoralist communities had restored and managed grazing territories.

4. Access and control over resources helped community collectives and village assemblies strengthen themselves financially. Money was invested in meeting immediate local needs before outside financial help could be mobilised.

5. Forest ownership ensured better livelihood opportunities during lockdown as communities continued to collect forest produce for sale and pay community members a daily wage.

These examples show that when local institutions have resources and power, they can help the most vulnerable and weak in society, including women, children and poor people. Long-term protection of biodiversity and agro-biodiversity helps communities be more resilient in crises.

\section{Case study 4: Community rights in France}

Mont Mourex is a hill in France overlooking Geneva, Switzerland. Since the Middle Ages, part of it has belonged to, and is managed by, the inhabitants of the hamlet of Mourex, part of the village of Grilly. This form of land management, a section de commune, is rare in France as communal lands are usually owned by the village town hall. Today this area serves agricultural and forest livelihoods, but is also an important place for recreation. In Mourex, local people identify strongly with their lands (Smith, 2020).
When COVID-19 struck France, according to one female community member, people felt "very fortunate to have access to our community lands, where we typically collect firewood, exercise our dogs, walk or collect mushrooms". However, outsiders started using the area, despite a $1 \mathrm{~km}$ restriction on movement. The mayor then closed access to communal lands to community members and outsiders, without consulting the local community of Mourex, the legal owners. This was considered a "usurpation of authority" by one community member. Many others were angered, one woman noting that it "concentrated people into other areas of the territory" so that - as another community member noted - "we met MORE people after the closure of our area (Mont Mourex) than when it was open", thus increasing the potential for COVID-19 transmission.

However, some good has emerged from these restrictions. Being forced onto other paths meant that community members discovered new areas of the village lands. Restricting people to their gardens and the street created a new sense of community. Members supported each other through a WhatsApp group. People met neighbours that they did not know. For some, it became a learning opportunity, for example gardening for the first time.

\section{Economic effects}

The survey indicated that economic impacts were mixed between livelihood loss (21 per cent), changes in movement (19 per cent), and disruption of selling goods ( 8 per cent). We found 36 per cent of the stories were combinations of all three (Fig. 5). Job loss, especially

\section{changes in movement of people}

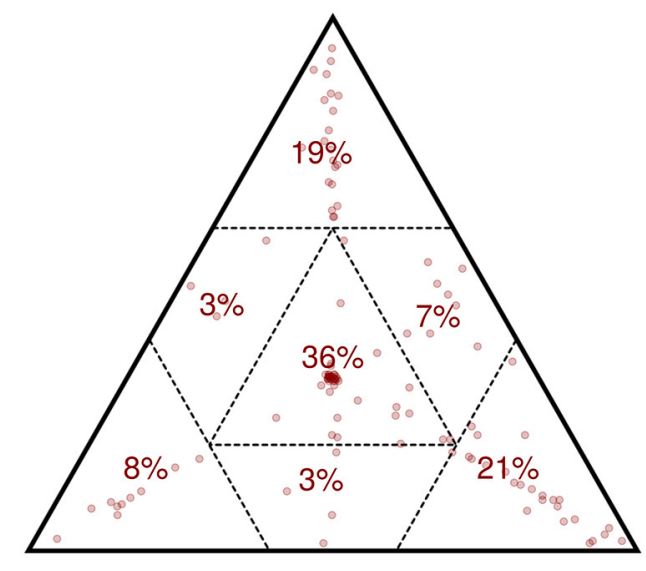

disruption of loss of jobs or selling goods

Figure 5. In many stories, people reported loss of livelihoods and changes in movement of people, or combinations of several factors 
from the collapse of tourism, was mentioned in Fiji, Gabon, Hawaii, Pakistan and Tanzania. Elsewhere, communities were affected when NGOs cut back their work to minimise COVID-19 transmission (e.g. reducing gorilla survey teams); with less work, people, mainly youth, returned to their home communities. The case from Benin shows how closing markets can have a negative impact on the ability of IPLCs to provide basic needs, including buying and selling products.

Case study 5: Food security in Benin

In Benin, COVID-19 has significantly affected local food production systems, which were already weak. Avrankou, one of the 77 communes, is inhabited by 17 IPLCs including the Torri, Goun, Yoruba and Nago. Each community has forests, natural sites, sacred water sources and other natural resources - places for celebrating and perpetuating community ties. The government imposed enormous restrictions on communities. According to one respondent, "We carry out income-generating activities such as gardening, fish farming, beekeeping. Its activities allowed us to meet certain subsistence needs and given ... the arrival of the confinement we found ourselves unable to resell our products which leads us today to have no more financial and material resources."

From March to May 2020, communities did not have access to markets to sell or buy basic necessities. Thus, to avoid famine, they were forced to consume traditional seeds from their seed banks (for example Phaseolus vulgaris, Zea mays, Dioscorea alata, Dioclea hexandra, Abrus precatorius, Caesalpinia bonduc). These have not been genetically modified (and are used as food, for cultural and religious ceremonies and in traditional medicine). During this time, the Groupe de Recherche et d'Action pour le Bien-Etre au Bénin helped more than 2,200 community members to respect social distancing measures and discussed with them the challenges of food sovereignty during a pandemic. Today, markets have reopened, and agricultural production, community dialogue and training in agroecology have slowly resumed.

Case study 6: From tourism to school closure in a coastal Gabonese community

Gabon contains 13 land and 17 marine protected areas, with the ecotourism sector at the heart of its conservation model. Loango is considered an exemplary park for tourism, generating jobs and income, and avoiding dependence on the oil-rich economy. Ecotourism has become central to the debate between “conserve or exploit” (Méral, 2011).
COVID-19 has been a major blow to tourism, especially for local communities, such as the Ngové people in Loango National Park. The Ngové settled at Iguéla lagoon long before the arrival of the Portuguese at Pointe Catherine in 1474 (Deschamps, 1962). Before the creation of the modern parks, they lived mainly from traditional fishing, gathering, hunting and agriculture. Today, the forest and lagoon provides for subsistence, medicinal and cultural needs (Agondjo-Okawe, 1982).

The introduction of travel restrictions led to a drop in international tourists and a drastic loss of income to both tourist operators and the people that they hire. Some tourist operators were forced to lay-off staff and even to cease work permanently, affecting community projects funded by tourism. An example is the village school of Tchangorovié, which provides free schooling for the children of the Indigenous community living in the park. It is a private school, founded in 2007 through a project between the local communities and the Gabonese Parks Agency. Teachers' salaries were paid from community tourism revenues ${ }^{4}$. Nearly 1,000 children have attended the school, with a success rate in national exams of 90 per cent over 13 years. With the closure of the lodge, the school also risks closure if governmental support cannot be found, illustrating the dangers of over-dependence on tourism. The local community needs other sources of income to fund its educational needs reliably.

Indigenous or local practices

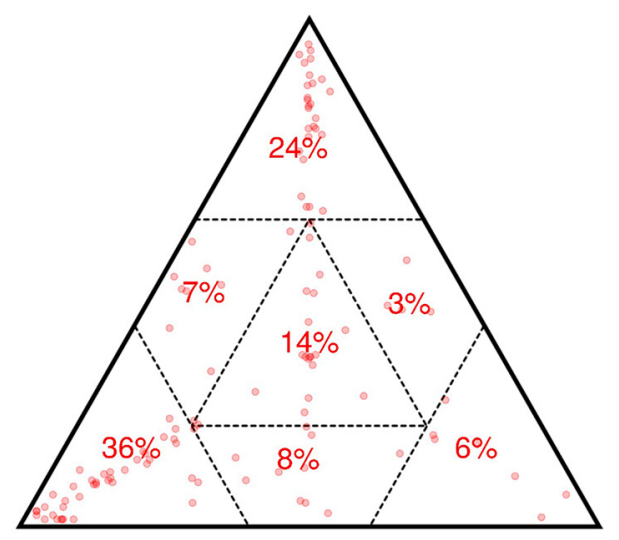

government

non-profit organisations

Figure 6. Respondents reported a mixture of management of COVID-19 responses from the government, Indigenous or local practice, but less often from non-profit organisations 


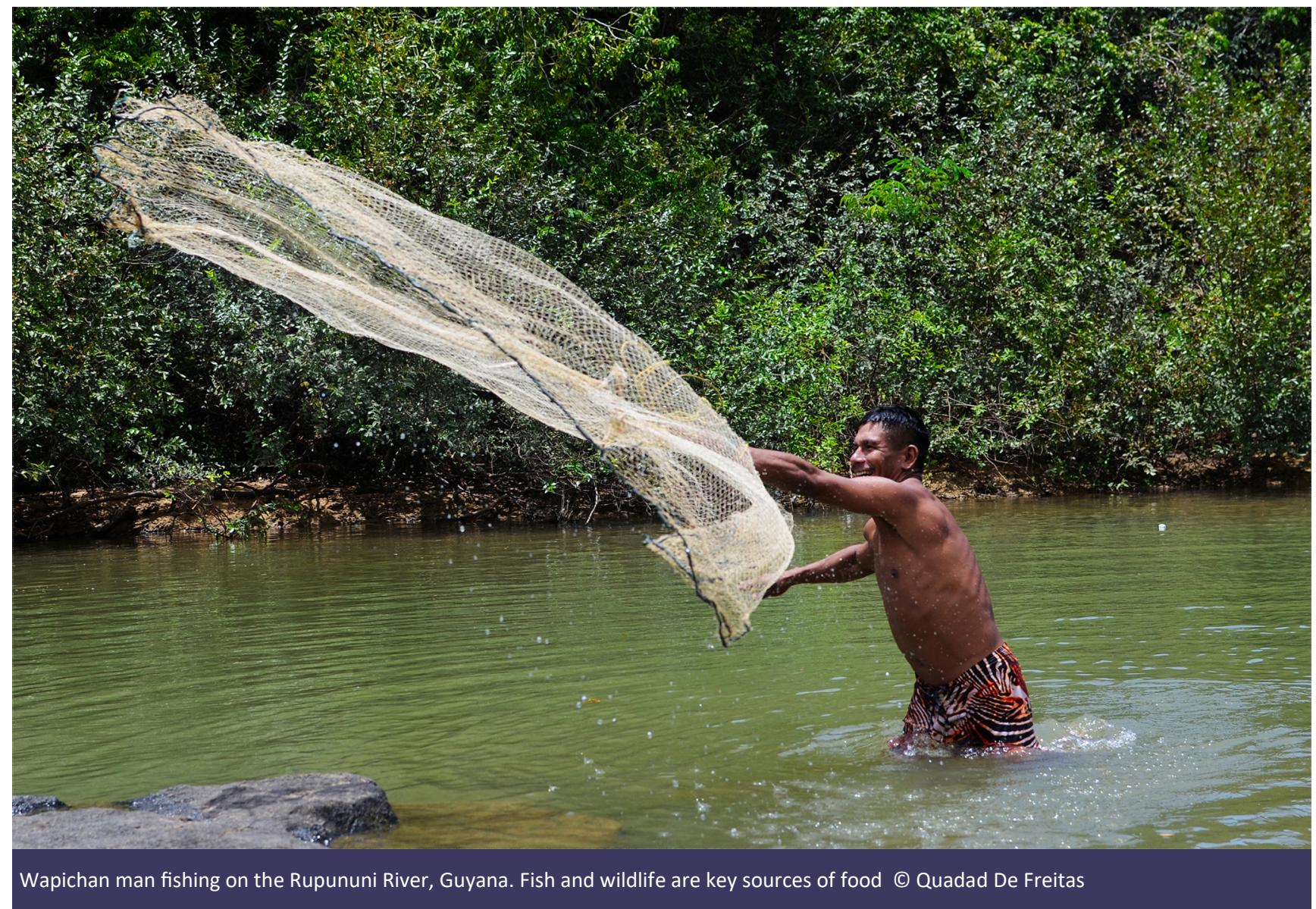

\section{Roles of communities and governments in dealing with COVID-19}

In 36 per cent of cases, the government was perceived as important in managing COVID-19 responses; 24 per cent thought Indigenous and local practices were more important; in 6 per cent of cases non-profit organisations were perceived to be managing COVID-19 (Fig. 6). In India, Bangladesh, Democratic Republic of Congo, Finland, France, Cameroon, Australia and Guatemala, stories stressed the failure of states to provide medical care. One Sami female reported that the intangible values of relationships in community and families had "been negatively affected" amongst reindeer herders.

Case study 7: Wapichan Wiizi response to COVID-19 in Guyana

The Wapichan Wiizi territory covers 2.8 million hectares, containing many globally rare or endangered animals and cultural heritage sites (Wapishan, 2012). It is managed by the South Rupununi District Council, an Indigenous overarching organisation, representative of 57 Indigenous communities. Wapichan Indigenous groups maintain traditional subsistence lifestyles of hunting, fishing and farming, but are increasingly involved in tourism, cattle ranching and commercialisation of farm and nature products (Conservation International Guyana and IDB, no date).

In the South Rupununi Region, the first concerns about COVID-19 arose in early April 2020 and the government swiftly closed all borders and banned gatherings of more than 10 persons. In the absence of medical facilities, local Indigenous leaders established a voluntary lockdown. Checkpoints were set up to control movements. Social control was effective in ensuring that all complied with safety measures. Movements of people between Guyana and Brazil were forbidden and movements of goods were only possible once a week at the Lethem border. The lockdown affected employment and income, particularly in tourism, transportation and trade. The trade of food products was particularly affected, and prices increased steadily. Local leaders took measures to raise awareness about the pandemic, distribute food to vulnerable households (e.g. elderly, disabled persons), and mainstream safety measures in public places.

From a food security perspective, households were generally well prepared: since schools were closed, 
people moved back to their old farming grounds deep in the forest, and relied on fishing, hunting and gathering. They increased farm size and started rearing chickens. Rapid adaptation was possible in households where knowledge of traditional practices had been maintained. Many leaders recognise the importance of maintaining traditional subsistence knowledge as adaptation capital during crises. Family cohesion, access to farming grounds, rivers and forests, and local knowledge gave households the capacity to adapt.

The pandemic also had social and cultural impacts. One man from the Annai group reported that it had "...made an impact that caused families and friends to separate and die, community members that were accustomed to living with one another closely had to find new ways to live with each other, self-help and other activities that require being together were no longer accepted by villages."

Traditional festivities that represent bonding opportunities for remote communities did not take place. The lockdown highlighted the importance of family cohesion, but also sometimes caused depression, drinking and intra-family violence. Local leaders have learnt to react quickly by raising awareness of the dangers and avoiding them. Traditional medicine and traditional fishing, hunting, farming and gathering have regained importance.

\section{Case study 8: COVID-19 response in Madagascar - NGOs and governments}

Vezo fishing communities, living on the arid southwest coast of Madagascar, are among the most remote and poorly served communities in the country. They rely almost entirely on the sea for food and income. Since 2003, the marine conservation organisation Blue Ventures has worked with these communities to help rebuild their fisheries. This community population of 12,000 relies on a network of community health workers and basic community health clinics for its health care needs, alongside support from traditional healers.

In close collaboration with community leaders and the Ministry of Health, Blue Ventures worked to reduce transmission of COVID-19, protect the most vulnerable and strengthen health systems. Actions included: providing accessible health information; establishing a community-based COVID-19 surveillance system; constructing handwashing stations and distributing washing equipment and soap; supporting local women's associations to manufacture reusable face masks; and developing new clinical protocols that minimise health worker-client transmission. Observations suggest social distancing guidelines are observed, 65 per cent of households are washing their hands with soap or ash, and 60 per cent wear a mask when leaving the home. At the time of writing (October 2020), all community health workers continue to provide services and clinics remain open, ensuring that essential health care delivery continues.

This work runs in parallel with efforts to ensure fishers can continue to earn a livelihood and manage their resources sustainably. Challenges are exacerbated by falling fish prices: a male Malagasy reports: "the sale of fishery products decreased significantly in quantity and price because the fish merchants/collectors slowed down their activity due to barrier measures". Successful adaptation by Vezo communities provides clear evidence of the effectiveness of a locally-led response to the pandemic which effectively coordinates input from all local stakeholders.

\section{DISCUSSION}

This initial analysis of the SenseMaker ${ }^{\circledR}$ surveys and case studies shows that COVID-19 has impacted communities in different ways. Though it is impossible to generalise, there are common themes. Based on the survey and cases studies, the following insights emerge: rapid adaptation was possible in households where knowledge of traditional practices had been maintained; there was a paradoxical increase in solidarity but also of separation of people who used to work and live together; traditional festivities that represent bonding opportunities for remote communities did not take place; local leaders have learnt to react quickly by raising awareness of the dangers and avoiding them; traditional medicine and traditional fishing, hunting, farming and gathering have regained importance; many villages made decisions to self-isolate from the rest of the country; and restrictions sometimes prevented communities from protecting their lands. Many stories centred on resource use and access, with community governance of their lands being at times reinforced and at times undermined. The interactions between governments, local people, the private sector and community leaders led both to innovations in dealing with COVID-19, and to restrictions that increased vulnerability of IPLCs. In this discussion, we focus on two themes: IPLC responses, and resilience and rights.

\section{IPLC responses}

Our study found the responses to COVID-19 varied across IPLCs and geographies, and were shaped by: (a) government responses to the health crisis; (b) impact of 
further crises or disturbances on top of COVID-19; (c) engagement in the formal economic sector; and (d) access to resources, especially food and traditional medicines. Health responses involved both NGOs partnering with communities, and communities acting alone. In Madagascar and Benin, international and national NGOs collaborated with communities to increase health services, providing critical support to communities in adopting governmental measures.

In many cases, the government was absent or unable to react quickly, and communities and their leaders stepped in. In Guyana, community leaders were able to act fast, despite a lack of medical facilities. In India, Adivasi communities with more rights could respond quickly, deciding to self-quarantine before governmental measures were enacted. In Guatemala, traditional medicine was used to counteract some COVID-19 symptoms. In other cases, such as Fiji, some were frustrated with the lack of leadership from their community leaders (e.g. to address poaching), while in France, the authoritarian shut-down of access to community lands angered the community and rendered them more vulnerable to disease transmission as they were forced into smaller outdoor spaces.

Our results are borne out elsewhere, largely from media reports in the early phases of the pandemic. Many

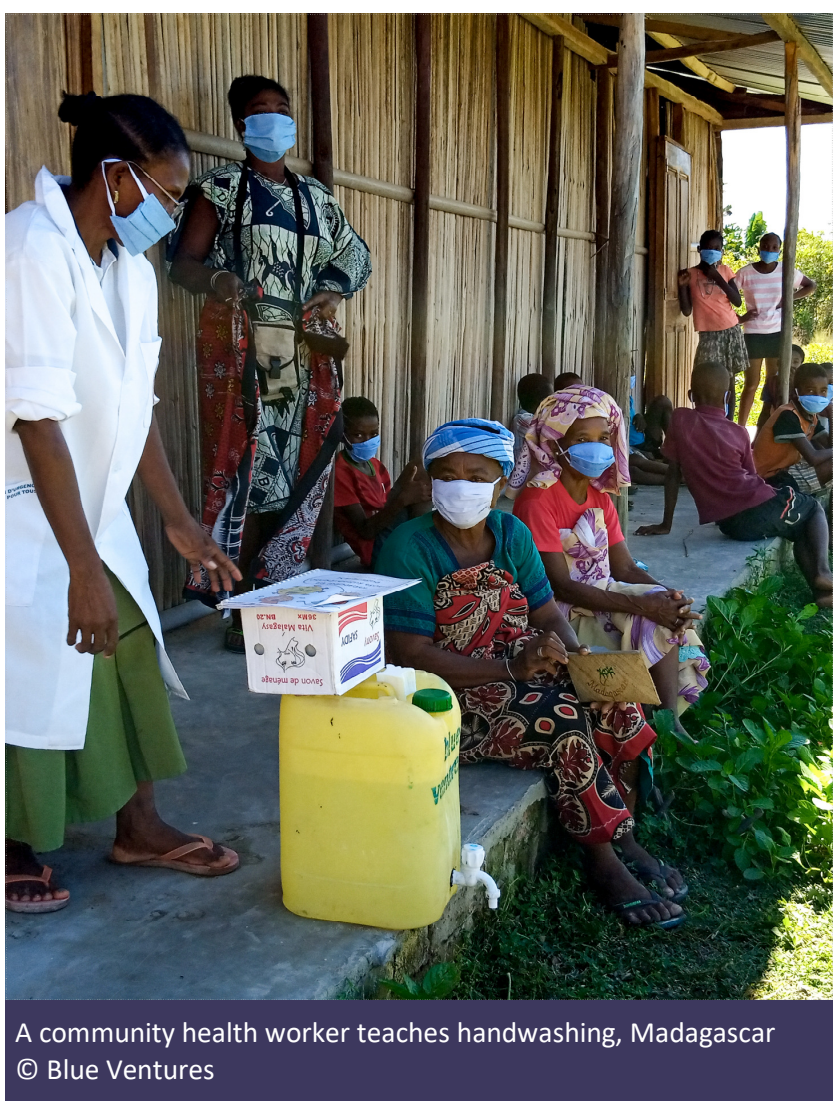

people returned to traditional practices and mutual selfhelp (Banning, 2020; The Lancet Diabetes \& Endocrinology, 2020). Some Canadian First Nations made extended stays on their lands to avoid COVID-19 and became more engaged in traditional practices (Banning, 2020). In the United States, Navajo youth helped elders (Gable, 2020) and Native Americans used traditional seeds and planted new gardens (Hoover, 2020). In Peru, the Autonomous Territorial Government of the Wampis Nation declared their territory to be a natural hospital, hosting plants for traditional medicine that can be used to stem COVID-19 symptoms (Carillo, 2020). The pandemic has renewed interest in traditional medicine and culturally relevant approaches to treatment of COVID-19 symptoms, and has emphasised the importance of locally led responses (Curtice \& Choo, 2020; United Nations, 2020). COVID19 responses should not be copied and pasted from elsewhere, or favour the elite, and traditional medicine should be supported (Iwuoha \& Aniche, 2020). Partnerships between governments and Indigenous peoples, which build on local knowledge, show good results in dealing with COVID-19 in Australia (Moodie et al., 2020), New Zealand (Carr, 2020) and Bolivia (Kaplan et al., 2020).

\section{Resilience and rights}

The survey and cases studies here demonstrate that IPLCs that are able to govern and access their lands and waters appeared to be more resilient. Through access, they were able to secure food and medicine for themselves and for outsiders and returning emigrants in need. With recognised tenure rights, they were able to enforce internal resource use regulations and often defend their territories from misuse by outsiders.

Tauli Corpuz, former United Nations (UN) Special Rapporteur on the rights of Indigenous peoples, notes that the absence of recognised rights over resources, isolation and small population size make them more vulnerable to the pandemic's economic and social impact (Hansen, 2020), so reducing their ability to safeguard their territories and monitor sites of concern, such as nearby mining concessions. But the news is not wholly negative, for example, some small-scale fishing communities have engaged in food sharing (Bennett et al., 2020); reduced movement by people has given nature a chance to recover; and while some countries have experienced a spike in poaching and other illegal activities, others have seen a reduction.

In Guyana, accessing fishing, hunting and gathering grounds and returning to traditional food production helped people survive. In India, Adivasi communities 


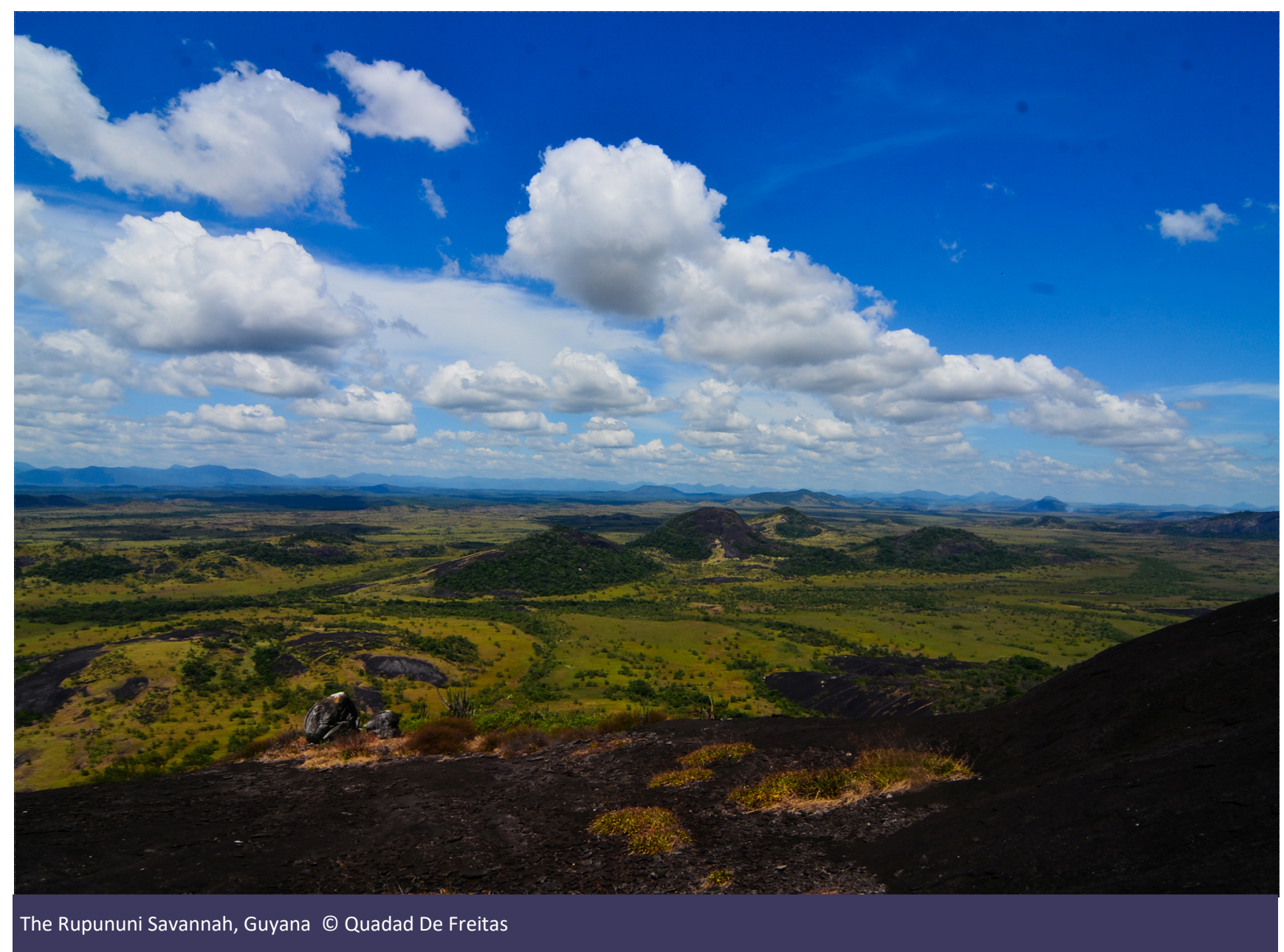

with forest rights continue to collect forest produce during the lockdown, enabling them to help outsiders. In Fiji, the practice of solesolevaki helped returning community members obtain shelter and food, while some community leaders were able to ensure compliance with customary rules for resource use and access. However, when a community outside a Gabon national park lost its fishing rights in the park, it was made more vulnerable to the pandemic.

Access to markets, much promoted by the development community, has both strengths and weaknesses in a situation like this. The communities in India, Fiji and Guyana did not depend solely on global markets; they appeared to fare better through self-reliance. However, resilience may break down under multiple crises: for example, the Fijian communities impacted by both COVID-19 and cyclones. Communities that were heavily dependent on markets for buying and selling, or jobs, generally fared worse. In Benin, communities had to eat their seed reserves since they did not have access to markets to purchase other food. Fisherfolk in
Madagascar suffered from falling fish prices; in Gabon, a local school, funded by tourism, is risking closure.

Lockdowns affected the ability of IPLCs to defend their lands. In Gabon, Guatemala, Cameroon and the Democratic Republic of Congo, people who were locked down noted that this policy did not apply to the extractive sectors - mining, logging and palm oil - even though these continued to operate, sometimes at the expense of community lands and helping to transmit COVID-19.

Resilience matters critically. There have been many reports that protected and conserved areas have been less well protected, and more vulnerable to poaching, during the pandemic. This study shows that where tenure is secure, there is resilience in IPLC communities, they have their own sources of food and they can take care of their territories within ICCAs. This is consistent with the observed linkages between ICCAs and increased food sovereignty (Pimbert et al., 2019). 
The COVID-19 pandemic demonstrates the limitations of the current funding model for protected and conserved areas and local peoples that depend on them, since this favours mainly states and operators, and may not directly fund local communities. Communities living near protected and conserved areas, who invested in wildlife tourism and rely on income from visitors, are now struggling (Corlett et al., 2020; Evans et al., 2020; Lindsey et al., 2020). There is a need to find alternative funding for protected and conserved areas (Rakhmatova, 2015; Cumming, 2021). The varied responses have challenged the narrative that only international tourism and aid can support IPLCs.

The survey offers evidence that people are not only surviving but, in some cases, thriving in part due to their reliance on customary knowledge, systems and practices. New models should consider the rights of communities while respecting and protecting nature. This requires their involvement as rightsholders in the governance and management of protected and conserved areas, as well as partners in revenue-sharing activities (e.g. Fabry \& Zeghni, 2012).

Communities need rights to land. Resilience of IPLCs is determined by their access to and use of nature, and an ability to govern and defend their lands and waters. The resources and the associated traditional knowledge which are being accessed during COVID-19 are invaluable in times of crisis and will continue to be an important safety net.

In some communities, over-reliance on NGOs or the government seems to reduce resilience, creating dependence on external funding or knowledge; however, effective collaboration between communities and NGOs can also lead to long-term capacity building and sustainability.

\section{Key actions to support IPLCs in pandemics and beyond}

How can IPLCs, managers of protected and conserved areas, NGOs, governments and companies work together respectfully in crises and beyond to encourage and protect resource rights and access to traditional crisis foods and medicines? Based on the results of this paper, we propose the following actions for dealing with the current and future pandemics:

1. A rights-based approach to crisis responses is needed, in which priority is given to tenure and rights as they pertain to communities governing their lands and territories.

2. Governments and development workers should recognise and protect the rights of IPLCs to govern their lands and territories because that is where the resources (water, food and medicine) needed to cope with pandemics are to be found.

3. Companies must not use crises as reasons to stop engaging with IPLCs or to move into their lands.

4. Crisis response measures to COVID-19 should: be jointly conceived with IPLCs; value diverse perspectives and approaches; and recognise the actions that many IPLCs undertake independently.

5. Governments and NGOs should learn from and disseminate COVID-19 success stories carried out by IPLCs.

6. Greater diversity of funding is needed for conservation initiatives that engage with IPLCs, with priority given to direct funding of ICCAs and local communities.

7. Long-term partnerships between protected and conserved areas and IPLCs are needed, which ensure that IPLCs' access to natural resources is not put at risk in times of crisis.

\section{ENDNOTES}

1. Adults were self-declared individuals who were considered of an adult age according to their country's laws.

2. https://www.iccaconsortium.org/index.php/category/covid19-en/

3. This section is written by Neema Pathak Broome, entirely based on and taken sometimes verbatim or summarised from the introduction section of Vikalpa Sangam and CFR-LA (2020). This has been done with due permission of all her colleagues and co-authors of the document.

4. Although Gabon has a small population of 1.8 million, the population is concentrated in the cities of Libreville and PortGentil, leaving the hinterland underpopulated by comparison. The priority areas for investment are de facto urban centres, thus causing most educational funding to be distributed to urban schools. The school of Iguéla functions entirely by income resulting from tourism paid by the lodge concessionaire; however, this situation is currently being reviewed by the government.

\section{ACKNOWLEDGEMENTS}

We would like to acknowledge the following people and Indigenous organisations who contributed to the development and testing of the survey: Holly Jonas, Natividad Quillahuamán, Eleonora Fanari, Samuel Nnah, Teri Tuxson, Amy Maling, Felipe Gomez, Anna Panagiotou, Ellie Snowden, South Rupununi Conservation Society, North Rupununi District Development Board, South Rupununi District Council. We thank the people who took the time to respond to the questionnaire. The University of Lausanne funded this study. We thank two anonymous reviewers and the two editors of the Special Issue for their comments that improved this paper. 


\section{ABOUT THE AUTHORS}

Gretchen Walters, French community rightsholder. Assistant Professor, University of Lausanne. Member WCPA, CEESP, SSC, SULi. ${ }^{\dagger}$

Neema Pathak Broome - Programme Coordinator Conservation and Livelihoods Programme, and ICCA Consortium South Asia Regional Coordinator.

Marina Cracco, Researcher at the University of Lausanne; member WCPA and CEM.

Tushar Dash - researcher on forest rights and governance issues in India with tribal and forest dwelling communities and the Forest Rights Act.

Nigel Dudley, freelance ecologist, based in Wales, UK. Member of WCPA, CEESP, CEM ${ }^{\dagger}$.

Silvel Elías, Maya Kíché, Professor, University of San Carlos, Guatemala†.

Olivier Hymas - Conservation practitioner/ researcher, biologist and anthropologist. specialising on impacts of industries and conservation on rural communitiest.

Sangeeta Mangubhai, Member Fiji Locally Managed Marine Area network, Pew marine conservation fellow*.

Vik Mohan is a UK-based doctor and Director of Community Health at Blue Ventures*.

Thomas Niederberger, Coordinator for Research and Publications, ICCA Consortium; PhD (des) University of Bern, Switzerland.

Christy Achtone Nkollo-Kema Kema, Technical Research Assistant, Department of Geography, Omar Bongo University, Gabon.

Appolinaire Oussou Lio, geographer-naturalist, Expert in Earth Jurisprudence, President of GRABEBENIN ONG*.

Njaka Ravelosonn the National Technical Advisor for Health at Blue Ventures Madagascar*.

June Rubis, a Bidayuh woman from Sarawak, and coChair of ICCA Documenting Territories of Life.

Mathieu S.A.R. Toviehou, Geographer-naturalist, Engineer of development and planning, Executive Director, GRABE-BENIN ONG*.

Nathalie van Vliet, CIFOR associate researcher, focusing on wildlife and livelihoods in Africa and Latin Americat.

† Honorary members of ICCA Consortium

* Member of ICCA Consortium

\section{REFERENCES}

Agondjo-Okawe, P.L. (1982). Représentations et organisations endogènes de l'espace chez les Myènès du Gabon (Nkomi et Mpongwè) in Enjeux foncier en Afrique Noire. Karthala.

Banning, J. (2020). 'How Indigenous people are coping with COVID-19', CMAJ, 192(27), E787-E788. doi: 10.1503/ cmaj.1095879.

Bates, A.E., Primack, R.B., Moraga, P. and Duarte, C.M. (2020). 'COVID-19 pandemic and associated lockdown as a "Global Human Confinement Experiment" to investigate biodiversity conservation', Biological Conservation, 248, 108665. doi: 10.1016/j.biocon.2020.108665.

Bayha, M. and Spring, A. (2020). 'Response to COVID in Délinę, NT: reconnecting with our community, our culture and our past after the pandemic', Agriculture and Human Values, 37 (3), 597-598. doi: 10.1007/s10460-020-10059-z.

Belaïdi, N. and Koubi, G. (2020). 'Covid-19 et peuples autochtones : Des "faits informatifs" sur une relation au monde (Enquête de mars à juin 2020)', Revue des droits de l'homme. doi: 10.4000/revdh.10441.

Bennett, N.J., Finkbeiner, E.M., Ban, N.C., Belhabib, D., Jupiter, S. and Kittinger, J.N. (2020). 'The COVID-19 Pandemic, SmallScale Fisheries and Coastal Fishing Communities', Coastal Management, 48(4), 336-347. doi: 10.1080/08920753.2020.1766937.

Bernard, H.R. (2017). Research Methods in Anthropology: Qualitative and Quantitative Approaches. 6th edition. Rowman \& Littlefield.

Carillo, K. (2020). The Wampis Nation declares its integral territory as a natural hospital, ICCA Consortium. Available at: https:// www.iccaconsortium.org/index.php/2020/09/19/wampisdeclares-integral-territory-natural-hospital/.

Carr, A. (2020). 'COVID-19, indigenous peoples and tourism: a view from New Zealand', Tourism Geographies, 22(3), 491502. doi: 10.1080/14616688.2020.1768433.

Comunidad Maya Los Chenes (2020). Plantas medicinales del Pueblo Maya en tiempos de COVID-19. Los Chenes, Campeche, México. Available at: https:// www.educaoaxaca.org/wp-content/uploads/2020/05/PlantasMedicinales-del-Pueblo-Maya-May20.pdf.

Conde, M. (2020). 'Brazil in the Time of Coronavirus', Geopolítica (s), 11(Especial), 239-249. doi: 10.5209/geop.69349.

Conservation International Guyana and Inter-American Development Bank (no date). The State of Food and Agriculture in the Rupununi, Guyana.

Cook, N.D. and Lovell, W.G. (eds) (1991). Secret judgments of God: Old World disease in colonial Spanish America. 1st ed. International Congress of Americanists, Norman: University of Oklahoma Press (The Civilization of the American Indian series).

Corlett, R.T., Primack, R.B., Devictor, V., Mass, B., Goswami, B., Bates, A. et al. (2020). 'Impacts of the coronavirus pandemic on biodiversity conservation', Biological Conservation, 246, 108571. doi: 10.1016/j.biocon.2020.108571.

Crooks, K., Casey, D. and Ward, J.S. (2020). 'First Nations peoples leading the way in COVID-19 pandemic planning, response and management', Medical Journal of Australia, 213 (4), 151-152.e1. doi: 10.5694/mja2.50704.

Cumming, T., Seidl, A., Emerton, L., Spenceley, A., Golden Kroner, R., Uwineza, Y. and van Zyl, H. (2021) Building 
sustainable finance for resilient protected and conserved areas - lessons from COVID-19. PARKS 27 (Special Issue): 149-160. doi: 10.2305/IUCN.CH.2021.PARKS-27-SITC.en

Curtice, K. and Choo, E. (2020). 'Indigenous populations: left behind in the COVID-19 response', The Lancet, 395 (10239),1753. doi: 10.1016/S0140-6736(20)31242-3.

Deschamps, H. (1962). Traditions orales et archives au Gabon. Paris: Berger-Levrault.

Evans, K.L., Ewen, J.G., Guillera-Arroita, G., Johnson, J.A., Penteriani, V., Ryan, S.J., Sollman, R., Gordon, I.J. (2020). 'Conservation in the maelstrom of Covid-19 - a call to action to solve the challenges, exploit opportunities and prepare for the next pandemic', Animal Conservation, 23(3), 235-238. doi: 10.1111/acv.12601.

Fabry, N. and Zeghni, S. (2012). 'Tourisme et développement local: une application aux clusters de tourisme', Mondes en développement, $n^{\circ} 157(1)$, 97. doi: 10.3917/med.157.0097.

Gable, M. (2020). As Covid-19 tears through Navajo Nation, young people step up to protect their elders. Statnews, 26 May. Available at: https://www.statnews.com/2020/05/26/ navajo-nation-covid-19-youth-response-elders-health/.

Garnett, S.T., Burgess, N.D., Fa, J.E., Fernández-Llamazares, A., Molnár, Z., Robinson, C.J., Watson, J.E.M et al. (2018). A spatial overview of the global importance of Indigenous lands for conservation. Nature Sustainability, 1(7), 369. doi: 10.1038/s41893-018-0100-6.

Hansen, T. (2020). How Covid-19 could destroy indigenous communities. Available at: https://www.bbc.com/future/ article/20200727-how-covid-19-could-destroy-indigenouscommunities.

Hoover, E. (2020). Native food systems impacted by COVID. Agriculture and Human Values, 37(3), 569-570. doi: 10.1007/ s10460-020-10089-7.

IACHR (2020). IACHR Warns of the Specific Vulnerability of Indigenous Peoples to the COVID-19 Pandemic, Calls on States to Adopt Targeted, Culturally Appropriate Measures that Respect These Peoples' Land. Available at: http:// www.oas.org/en/iachr/media_center/

PReleases/2020/103.asp.

Iwuoha, V.C. and Aniche, E.T. (2020). Covid-19 lockdown and physical distancing policies are elitist: towards an indigenous (Afro-centred) approach to containing the pandemic in suburban slums in Nigeria. Local Environment, 25(8), 631-640. doi: 10.1080/13549839.2020.1801618.

Kaplan, H.S., Trumble, C.B., Stieglitz, J., Mamany, R.M., Cayuba, M.G., Moye, L.M. et al. (2020). Voluntary collective isolation as a best response to COVID-19 for indigenous populations? A case study and protocol from the Bolivian Amazon. The Lancet, 395(10238), 1727-1734. doi: 10.1016/S0140-6736 (20)31104-1.

Lindsey, P., Allan, J., Brehony, P., Dickman, A., Robson, A., Begg, C., et al. (2020). Conserving Africa's wildlife and wildlands through the COVID-19 crisis and beyond. Nature Ecology \& Evolution, 4(10), 1300-1310. doi: 10.1038/s41559020-1275-6.

Mangubhai, S., Sykes, H., Lovell, E., Brodie, G, Jupiter, S., Morris, C. et al. (2019). Fiji: Coastal and marine ecosystems. In C. Sheppard (ed.) World Seas: An Environmental Evaluation Volume II: The Indian Ocean to the Pacific. London, United Kingdom: Elsevier, 765-792.

Meneses-Navarro, S., Freyermuth-Enciso, M.G., PelcastreVillafuerte, B.A., Campos-Navarro, R., Melendez-Navarro, D.M. and Gomez-Flores-Ramos, L. (2020). The challenges facing indigenous communities in Latin America as they confront the COVID-19 pandemic. International Journal for Equity in Health, 19(1), 63. doi: 10.1186/s12939-020-01178-4.

Méral, P. (2011). Tourisme et conservation: tentations africaines. In G. Froger (ed.) Tourisme durable dans les Suds? Paris, France: PIE Peter Lang - coll. EcoPolis.

Milne, K.M.G. (2015). Can sense-making tools inform adaptation policy? A practitioner's perspective. Ecology and Society, 20 (1). doi: 10.5751/ES-06791-200166.

Moodie, N., Ward, J., Dudgeon, P., Adams, K., Altman, J., Casey, D. et al. (2020). Roadmap to recovery: Reporting on a research taskforce supporting Indigenous responses to COVID-19 in Australia. Australian Journal of Social Issues, (n/ a), 1-13. doi: 10.1002/ajs4.133.

Omoding, J., Walters, G.M., Edward, A., Carvvalho, S., Colomer, J., Cracco, M., et al. (2020). Analysing stakeholder perceptions to improve protected area governance in Ugandan conservation landscapes. Land, 9, 207-231.

Pimbert, M.P. and Borrini-Feyerabend, G. (2019). Nourishing lifeterritories of life and food sovereignty, Policy Brief of the ICCA Consortium no. 6. ICCA Consortium, Centre for Agroecology, Water and Resilience at Coventry University and CENESTA, Tehran.

Power, T., Wilson, D., Best, O., Brockie, T., Bourque Bearskin, R.L., Millender, E. and Lowe, J. (2020). COVID-19 and Indigenous Peoples: An imperative for action. Journal of Clinical Nursing, 29(15-16), 2737-2741. doi: 10.1111/ jocn. 15320.

Rakhmatova, Z.M. (2015). Tourisme et autonomisation des communautés locales. Le cas de la région du Pamir Tadjik. Téoros, 34(34, 1-2). Available at: http:// journals.openedition.org/teoros/2792 (Accessed: 27 October 2020).

Rights and Resources Initiative (2020). Rights-Based Conservation: The path to preserving Earth's biological and cultural diversity? Washington, DC: Rights and Resources Initiative.

Sajeva, G., Borrini-Feyerabend, G. and Niederberger, T. (2019). Meanings and more... 7. Available at: https:// www.iccaconsortium.org/wp-content/uploads/2019/11/ICCABriefing-Note-7-Final-for-websites.pdf.

Santos, V.S., Souza Araújo, A.A., Ribeiro de Oliveira, J., Quintans-Júnior, L.J. and Martins-Filho, P.R. (2020). COVID-19 mortality among Indigenous people in Brazil: a nationwide register-based study. Journal of Public Health. doi: 10.1093/pubmed/fdaa176.

Smith, G. (2020). The section de commune of Mourex, France. A "power to be heard, to defend what is precious to us". Série Développement, Sociétées, Environnements, Université de Lausanne, 2e, p. 30.

The International Work Group for Indigenous Affairs (IWGIA) and International Labour Organization (ILO) (2020). The impact of COVID-19 on indigenous communities: Insights from the Indigenous Navigator. Available at: https://www.ilo.org/gender/ Informationresources/Publications/WCMS_757475/lang--en/ index.htm.

The Lancet (2020). Self-determination and Indigenous health. The Lancet, 396(10248), 361. doi: 10.1016/S0140-6736(20)316822 . 
The Lancet Diabetes \& Endocrinology (2020). Indigenous peoples: resilience in the face of adversity. The Lancet Diabetes \& Endocrinology, 8(9), 731. doi: 10.1016/S2213-8587(20)30273 -4 .

United Nations (2020). The Impact of COVID-19 on Indigenous Peoples. Department of Economic and Social Affairs Policy Brief, 70.

Van der Merwe, S.E., Biggs, R., Preiser, R., Cunningham, C., Snowden, D.J. and Jenal, M. (2019). Making Sense of Complexity: Using SenseMaker as a Research Tool. Systems, 7(2), 25. doi: 10.3390/systems 7020025.

Vikalp Sangam and CFR-LA (2020). Community forest rights and the pandemic: Gram Sabhas lead the way. Volume 2 of the extraordinary work of 'ordinary people - beyond pandemics and lockdowns' series and Bulletin 5 of COVID-19 and forest rights. India. Available at: http://vikalpsangam.org/static/ media/uploads/Perspectives/

cfr_and_the_pandemic_gs_lead_the_way_bulletin_5_oct202 0. pdf.
Wapishan, P. (2012). Baokopa'o wa di'itinpan wadauniinao ati'o nii (Thinking together for those coming behind us: An outline plan for the care of Wapichan territory in Guyana). South Rupununi, Guyana: South Central and South Rupununi Districts Toshaos Councils. https://www.lifemosaic.net/ images/uploads/Territories_of_Life/TOL_Resources/ Plan de Vida/ Thinking_Together_For_Those_Coming_Behind_Us.pdf

Wildlife Conservation Society and LMMA Network (2020). COVID19 Update \#1: Fiji. Available at: https:// Immanetwork.org/wp-content/uploads/2020/08/WCS-Fiji-andLMMA-Network.-Covid-Update-1-Fiji.-26.05.2020.pdf.

World Bank (2020). Indigenous peoples. Available at: https:// www.worldbank.org/en/topic/ indigenouspeoples\#: :text=There\%20are\%20approximately\% 20476 per cent20million, $\% \% \% 20$ of $\% 20$ the $\% 20$ extreme $\%$ 20poor (Accessed: 28 October 2020).

\section{RESUMEN}

Informamos sobre la forma en que la pandemia del COVID-19 está afectando a los pueblos indígenas y las comunidades locales, especialmente a los que gobiernan, gestionan y conservan sus tierras y aguas. Exploramos los temas de acceso y uso de los recursos naturales, la solidaridad, la toma de decisiones, el papel de los gobiernos y los IPLC (pueblos indígenas y comunidades locales -PICL) en la gestión del COVID-19, y la adopción de la medicina tradicional. Estos temas se examinan a través de una encuesta mundial en línea en inglés, español y francés. Recopilamos y analizamos 133 encuestas de 40 países, utilizando SenseMaker $®$, un software que permite el análisis de micronarrativas basadas en la forma en que los entrevistados clasifican sus propias historias. Exploramos más a fondo los temas mediante estudios de caso de Benín, Fiyi, Francia, Gabón, Guyana, Guatemala, India y Madagascar, destacando los desafíos y oportunidades en términos de la forma en que los pueblos indígenas y las comunidades locales reaccionaron ante el COVID-19. Nuestro estudio subraya la importancia de la autonomía y el reconocimiento de los derechos de los PICL, que les permite utilizar la medicina tradicional, satisfacer las necesidades de subsistencia durante los cierres, ayudar a los miembros y vecinos de la comunidad a mantener los medios de vida, y a gobernar, defender y conservar sus territorios. Proponemos medidas clave para apoyar a los pueblos indígenas y las comunidades locales a defenderse de futuras pandemias, protegiendo al mismo tiempo sus tierras y aguas.

\section{RÉSUMÉ}

Nous rendons compte de la façon dont la pandémie de COVID-19 affecte les peuples autochtones et les communautés locales (PACL), en particulier celles qui gouvernent, gèrent et conservent leurs terres et leurs eaux. Nous explorons les thèmes de l'accès et de l'utilisation des ressources naturelles, de la solidarité, de la prise de décision, du rôle des gouvernements et des PACL dans la gestion de la COVID-19, et de l'adoption de la médecine traditionnelle. Ces thèmes sont explorés à travers une enquête mondiale en ligne en anglais, espagnol et français. Nous avons recueilli et analysé 133 enquêtes dans 40 pays, à l'aide de SenseMaker®, un logiciel qui permet d'analyser les micro-narrations en fonction de la façon dont les répondants classent leurs propres histoires. Nous explorons les thèmes plus en détail à travers des études de cas provenant du Bénin, des Fidji, de la France, du Gabon, de la Guyane, du Guatemala, de l'Inde et de Madagascar, mettant en évidence les défis et les opportunités dans la manière dont les peuples autochtones et les communautés locales ont répondu à la COVID-19. Notre étude souligne l'importance de l'autonomisation et de la reconnaissance des droits des PACL qui leur permet d'utiliser des médicaments traditionnels, de répondre aux besoins de subsistance pendant les confinements, d'aider les membres de la communauté et les voisins à maintenir leurs moyens de subsistance et de gouverner, défendre et conserver leurs territoires. 